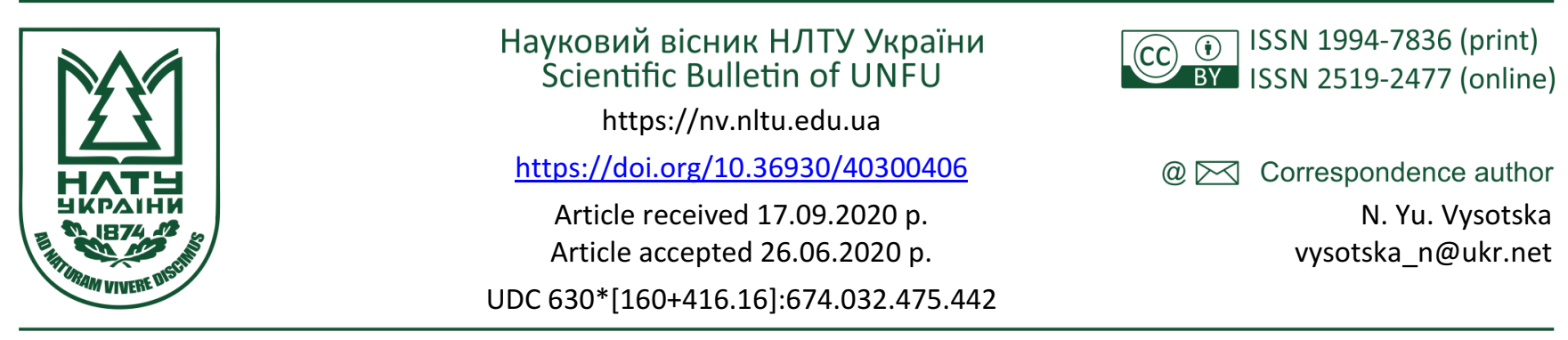

Н. Ю. Висоцька ${ }^{1}$ В. А. Дишко ${ }^{1}$, М. М. Михайличенко ${ }^{1}$, О. І. Хромуляк², В. о. Климко ${ }^{2}$

${ }^{I}$ Украӥнський науково-дослідний інститут лісового господарства та агролісомеліорації ім. Г. М. Височького, м. Харків, Украӥна

${ }^{2}$ ДП "Київська лісова науково-дослідна станиія УкрНДІЛГА", с. Лютіж, Украӥна

\title{
ОСОБЛИВОСТІ МЕТАБОЛІЗМУ СОСНИ ЗВИЧАЙНОЇ В ОСЕРЕДКАХ УСИХАННЯ У КИЇВСЬКОМУ ПОЛІССІ
}

\begin{abstract}
За умов глобальної зміни клімату зростає актуальність досліджень, спрямованих на підвищення продуктивності і біологічної стійкості лісів. Особливо увагу привертають дослідження сосни звичайної (Pinus sylvestris L.), яка займає широкий ареал і характеризується складною внутрішньовидовою структурою. Одним із чинників абіотичного стресу для сосни звичайної є спалахи масового розмноження стовбурових комах-шкідників. Рослини, які періодично перебувають під впливом стресу, вимушені адаптуватися до нього шляхом фізіолого-біохімічної та анатомо-морфологічної перебудови. Отже, важливим аспектом формування стійких до стрес-чинників, зокрема до нападу комах, соснових деревостанів є біохімічна індикація стану дерев, для якої використовують продукти основного обміну та вторинні метаболіти. У Київському Поліссі в осередку "короїдного" усихання досліджено морфологічні параметри хвої, а також вміст водорозчинних білків і низькомолекулярних сполук фенольної природи (флавонолів - у хвої; катехінів, проантоціанідинів - у хвої та лубі) у деревах сосни звичайної (Pinus sylvestris L.). Вміст білків і фенольних сполук визначали колориметричним методом за загальноприйнятими методиками. Встановлено відмінності вмісту сполук фенольної природи у лубі та хвої сосни звичайної. Вміст розчинних білків у хвої є істотно більшим, ніж у лубі, тоді як сполуки фенольної природи (проантоціанідини, катехіни) інтенсивніше накопичуються у лубі. Мінливість білкового синтезу, як у лубі, так і у хвої, є низькою. Сполуки флавоноли зафіксовані тільки у хвої. Не встановлено істотних залежностей між вмістом сполук фенольної природи і таксаційними показниками дерев сосни звичайної. На тлі масового всихання сосни звичайної в Київському Поліссі серед ослаблих дерев для більш стійких екземплярів характерна висока активність білків, що залучені до синтезу вторинних метаболітів, які чинять позитивний вплив на стійкість рослин в умовах дії стресорів.
\end{abstract}

Ключові слова: Pinus sylvestris L.; стрес; стійкість; метаболіти.

\section{Вступ}

Реакція рослин на стрес є генетично детермінованою й відображає їхню конкурентоспроможність, адаптивні можливості та стійкість до негативного впливу природних і антропогенних чинників [6]. Особливо увагу привертають дослідження сосни звичайної (Pinus sylvestris L.), яка займає широкий ареал і має складну внутрішньовидову структуру [14].

Однією 3 найважливіших ланок метаболізму є біосинтез білків, які тісно пов'язані з імунною системою рослин і виконують функції різного призначення $[4,9]$. Стреси часто призводять до припинення та пригнічення синтезу білків, які містяться у клітинах за нормального розвитку й індукують синтез специфічних стресових білків, характерних для відповіді на дію несприятливих чинників [16]. У лісових екосистемах цінними діагнос- тичними ознаками стійкості також є біометричні та біохімічні показники хвої [1].

В умовах Київського Полісся стресорами для деревостанів сосни звичайної стали тривалі посухи, високі температури повітря влітку, зменшення рівня грунтових вод, й на цьому тлі - фітопатогени й ксилофаги [12]. За дії цих стресових чинників відбувся перехід обміну речовин на новий режим функціонування, внаслідок якого резервні можливості організму об'єдналися завдяки внутрішньоклітинним і міжклітинним системам регуляції, що дало змогу ослабленим деревам зберегти життєздатність на тлі масового відпаду сосни звичайної. Зважаючи на низький рівень мінливості білкового синтезу [5], також доцільно приділяти увагу ролі низькомолекулярних фенольних сполук, які характеризуються високою антиоксидантною здатністю, вплива-

\section{Інформація про авторів:}

Висоцька Наталія Юріївна, канд. с.-г. наук, ст. наук. співробітник, перший заступник директора. Email: vysotska_n@ukr.net https://orcid.org/0000-0002-3033-2036

Дишко Валентина Андріївна, мол. наук. співробітник, лабораторія підвищення стійкості лісів. Email: valya_dishko@ukr.net Михайличенко Олександр Миколайович, наук. співробітник, лабораторія підвищення стійкості лісів. Email: muhaylich@ukr.net Хромуляк Олександр Ігорович, аспірант, лабораторія підвищення стійкості лісів; директор. Email: info@klnds.com.ua Климко Володимир Олександрович, аспірант, лабораторія підвищення стійкості лісів; головний лісничий. Email: info@klnds.com.ua

Цитування за ДСтУ: Висоцька Н. Ю., Дишко В. А., Михайличенко О. М., Хромуляк О. І., Климко В. О. Особливості метаболізму сосни звичайної в осередках усихання у Київському Поліссі. Науковий вісник НлтУ України. 2020, т. 30, № 4. С. 37-40.

Citation APA: Vysotska, N. Yu., Dyshko, V. A., Mykhaylichenko, A. N., Khromulyak, A. I., \& Klimko, V. A. (2020). Some features of metabolism of scots pine in the bark beetle focus in Kyiv Polissya. Scientific Bulletin of UNFU, 30(4), 37-40. https://doi.org/10.36930/40300406 
ють на процеси росту, розмноження, стійкості проти патогенів, а також на проникливість клітинних мембран і їхнє функціонування [15].

Об'єкт дослідження - сосна звичайна в осередку "короїдного" всихання в умовах Київського Полісся.

Предмет дослідження - вміст водорозчинних білків і низькомолекулярних сполук фенольної природи у хвої та лубі сосни звичайної.

Мета дослідження - визначити вміст водорозчинних білків і низькомолекулярних сполук фенольної природи (флавонолів - у хвої; катехінів, проантоціанідинів - у хвої та лубі сосни звичайної) в осередку "короїдного" всихання для з'ясування їхнього значення в оцінюванні стійкості сосни звичайної до стресу.

Для досягнення зазначеної мети потрібно виконати такі основні завдання дослідження:

- визначити вміст водорозчинних білків та сполук фенольної природи у лубі та хвої сосни звичайної;

- встановити зв'язок між довжиною хвої та санітарним станом дерев;

- встановити зв'язок між вмістом біохімічних сполук та таксаційними показниками дерев.

Наукова новизна отриманих результатів дослідження - вперше в умовах Київського Полісся в осередку "короїдного" усихання встановлено, що стійкіші екземпляри сосни звичайної характеризуються вищим вмістом білків у лубі.

Практична значущість результатів дослідження полягає у тому, що на основі визначення вмісту водорозчинних білків і сполук фенольної природи можна прогнозувати стійкість сосни звичайної в осередку "короїдного" усихання.

Матеріали та методи дослідження. Пілотним об'єктом для визначення вмісту білків і фенолів у хвої та лубі сосни звичайної в осередку "короїдного" всихання було насадження у Старопетрівському лісництві ДП "Київська ЛНДС", квартал 137, виділ 3. Вік насадження становить 81 рік, склад - $10 \mathrm{C3}$, бонітет - 1А, тип

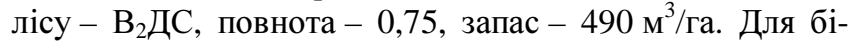
охімічних досліджень відібрано 8 модельних дерев, які за результатами обстеження характеризувалися III і IV категоріями санітарного стану. У цих дерев виміряли висоту $\left(h\right.$, м) і діаметр $\left(d_{1,3}\right.$, см) стовбура та вертикальну протяжність крони $\left(L_{\kappa}, \%\right)$ (таблиця). Для кожного дерева визначили перевищення середніх значень діаметра та висоти $\left(K_{1 d}, \%\right.$ та $\left.K_{1 h}, \%\right)$. Категорію стану дерева $(K c)$ сосни звичайної оцінювали за шестиступеневою шкалою: I - без ознак ослаблення, II - ослаблені, III - дуже ослаблені, IV - відмираючі, V - свіжий сухостій, VI старий сухостій [13].

Таблиця. Характеристика модельних дерев

\begin{tabular}{|c|c|c|c|c|c|c|c|}
\hline \multirow{2}{*}{$\begin{array}{c}\text { № } \\
\text { де- } \\
\text { рева }\end{array}$} & \multirow{2}{*}{$\begin{array}{c}\text { Діаметр, } \\
d_{1,3}, \mathrm{~cm}\end{array}$} & \multirow{2}{*}{$\begin{array}{c}\text { Висота, } \\
h, \mathrm{~m}\end{array}$} & \multirow[t]{2}{*}{$K_{1 d}$} & \multirow[t]{2}{*}{$K_{1 h}$} & \multicolumn{2}{|c|}{$\begin{array}{l}\text { Вертикальна про- } \\
\text { тяжність крони, } L_{\kappa p}\end{array}$} & \\
\hline & & & & & M & $\%$ & \\
\hline 1 & 40,5 & 28,0 & 11,1 & $-3,6$ & 8 & 28,6 & IV \\
\hline 2 & 44,0 & 27,6 & 18,2 & $-5,1$ & 7 & 25,4 & IV \\
\hline 3 & 33,0 & 29,6 & $-9,1$ & 2,0 & 7,6 & 25,7 & III \\
\hline 4 & 37,5 & 27,3 & 4,0 & $-6,2$ & 9,8 & 35,9 & $\overline{\text { IV }}$ \\
\hline 5 & 42,5 & 27,3 & 15,3 & $-6,2$ & 11,1 & 40,7 & III \\
\hline 6 & 41,5 & 30,5 & 13,3 & 4,9 & 74 & 24,3 & II \\
\hline 7 & 33,5 & 28,8 & $-7,5$ & $-0,7$ & 4,8 & 16,7 & $\overline{\text { IV }}$ \\
\hline 8 & 44,5 & 29,9 & 19,1 & 3,0 & 8,9 & 29,8 & II \\
\hline
\end{tabular}

Восени 3 центрального пагона верхівки зрубаних дерев відбирали зразки однорічної хвої (по 30 хвоїнок 3 кожного дерев $a)$. Довжину хвоїнок $\left(L_{x} b\right)$ вимірювали в лабораторних умовах, оцінювали рівень мінливості ознак [11]. На висоті 1,3 м з південного боку стовбура відокремлювали зразки лубу. Хвою і луб висушували до повітряно-сухого стану за кімнатної температури без доступу сонячного світла. Вміст водорозчинних білків (Б), флавонолів (Фл), катехінів (К $a)$ і зв'язаних проантоціанідинів (П $a)$ визначали за допомогою колориметра КФК-200 за довжини хвилі 615, 415, 500 і 550 нм, відповідно. Вміст білків у водних екстрактах із хвої і лубу визначали шляхом осадження їх кислим розчином амідо-чорного [3]. Вміст флавонолів визначали шляхом реакції екстракту в $70 \%$ етанолі з $\mathrm{AlCl}_{3}$ [2] (довжина хвилі 415 нм), катехінів - екстракту в $70 \%$ етанолі з $2 \%$ розчином ваніліну [7] (довжина хвилі 500 нм), а зв'язаних проантоціанідинів - гідролізом осаду від центрифугування етанольного екстракту $3 \mathrm{C}_{4} \mathrm{H}_{9} \mathrm{OH}: \mathrm{HCl}$ (95:5) (довжина хвилі 550 нм) [8].

Визначали коефіцієнт лінійної кореляції Пірсона між вмістом біохімічних сполук та таксаційними показниками дерев [10]. Гістограми побудовано за допомогою пакету програм MS Excel.

\section{Результати дослідження та їх обговорення}

Аналіз технічної документації (матеріально-грошова оцінка лісосіки № 5712; таксаційний опис) свідчить, що середні показники діаметра та висоти дерев, відведених У рубку $\left(d_{c e p .}=30 \mathrm{~cm} ; h_{\text {cep. }}=27,4 \mathrm{~m}\right)$, поступаються середнім показникам насадження $\left(d_{\text {cep }}=36 \mathrm{~cm} ; h_{\text {cep. }}=29,0\right.$ м $)$ на 16,6 і 5,5\% відповідно. Діаметри шести модельних дерев $\left(d_{\text {cep }}=36 \mathrm{~cm}\right)$ перевершують середні показники у насадженні $\left(K_{1-d}=4-19,1 \%\right)$, а двох поступаються $\left(K_{1-d}\right.$ $=7,5-9,1 \%)$. За висотою $\left(h_{c e p}=29\right.$ м) поступаються п'ять дерев $\left(K_{1-h}=0,7-6,2 \%\right)$, а перевершують - три $\left(K_{1-h}=2,0-4,9 \%\right)$.

Довжина хвої досліджуваних модельних дерев становила від 30 до 90 мм (рис. 1). Дерева № 3, 5, 6, 8 $(\mathrm{Kc}=\mathrm{III})$ мали більшу довжину хвої $L_{c e p} . \mathrm{Xв}=63,7^{ \pm 1,2}$ мм, ніж дерева № $1,2,4,7(K c=\mathrm{IV})-$ $L_{c e p} . \mathrm{Xв}=39,7^{ \pm 0,6}$ мм. Виявлено достовірне перевищення довжини хвої, зібраної з дерев III категорії санітарного стану $\left(F_{\text {qaкm. }}=313,9 ; \quad F_{0,05}=3,9\right)$. Результати дисперсійного аналізу свідчать про те, що збільшення довжини хвоїнок більше ніж у $32,3 \%$ випадків зумовлене впливом інших факторів.

Мінливість довжини хвої у групах дерев III та IV категорій санітарного стану оцінено коефіцієнтами варіації середнього рівня $\left(C v_{\mathrm{III}}=16,7 \% ; C v_{\mathrm{IV}}=13,5 \%\right)$. Найбільшим варіюванням відзначаються показники дерев № 1 і 8 (відповідно, $C v=14,5 \%, C v=16,2 \%$ ), а найменшим - № $4(C v=6,8 \%)$.

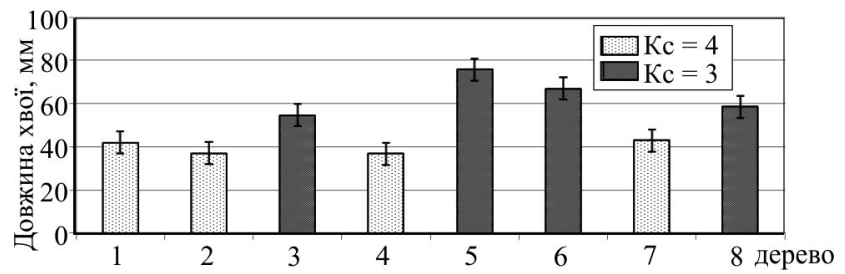

Рис. 1. Довжина хвої сосни звичайної в осередку всихання

Вміст первинних і вторинних метаболітів у хвої та лубі різниться (рис. 2). Для хвої характерні дещо вищий (на 4-18\%) вміст Б (Б луб $=16,5-18,2$ мг/г; $Б_{\text {хвоя }}=18,1-$ 20,3 мг/2) й істотно нижчий (у 2-6 разів), вміст сполук Па і Ка $\left(\right.$ Па $_{\text {луб }}=0,76-1,01 \mathrm{мг} / \Gamma ;$ Па $_{\text {хвоя }}=0,20-0,39 \mathrm{Mг} / \Gamma$; 
$\mathrm{Ka}_{\text {луб }}=0,20-0,49$ мг/г; К $\left.\mathrm{Ka}_{\text {хвоя }}=0,04-0,13 \mathrm{мг} / 2\right)$. Сполуки Фл зафіксовано тільки у хвої (Фл $=0,52-0,87$ мг/2). У лубі Фл не виявлено або ж їхній вміст є нижчим за поріг чутливості методу. Мінливість вмісту білків, як у лубі, так і у хвої є низькою $\left(C v_{л y \sigma}=3 \% ; C v_{\text {хвоя }}=4 \%\right)$, що підтверджує наші попередні дослідження [5]. Істотнішою мінливістю відзначений метаболізм фенолів $(C v=9-46 \%)$, які розглядають у ролі головних універсальних фізіологічних адаптерів проти несприятливих чинників середовища. При цьому, вміст фенольних сполук у хвої варіює більше, ніж у лубі (у хвої $C v=17-$ $46 \%$; у лубі $C v=9-32 \%$ ). Найбільшою мінливістю відзначаються сполуки Ка (у хвої $C v=46 \%$; у лубі $C v=32 \%)$.
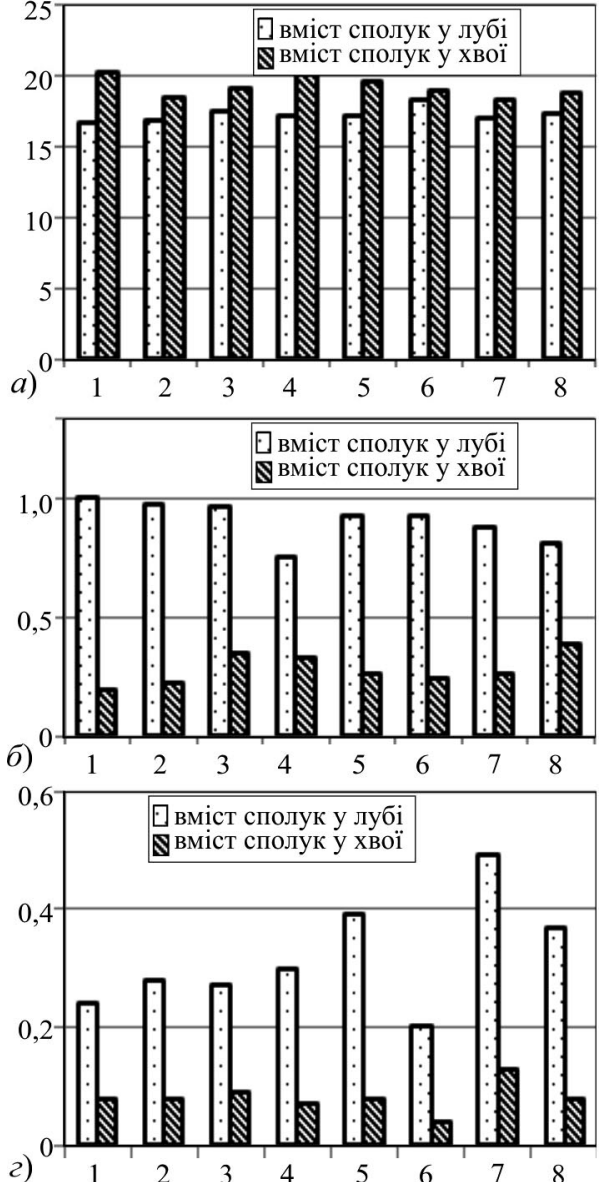

Pис. 2. Особливості накопичення водорозчинних білків і сполук фенольної природи у лубі та хвої сосни звичайної в осередках "короїдного" усихання: $a$ ) - вміст білків (Б), мг/г; б) - вміст проантоціанідинів (Па), мг/г; г) - вміст катехінів (Ка), мг/г; 18 - № дерев

Зважаючи на важливість біохімічного синтезу у питаннях стійкості, було також простежено кореляційні зв'язки між вмістом визначених нами сполук і таксаційними показниками дерев. Вміст білків у лубі тісно корелює тільки з висотою дерев (рис. $3, a$ ), достовірність такого зв'язку підтверджена статистично $(r=0,73)$. Так, дослідженнями [5] встановлено, що вміст проантоціанідінів та катехінів у лубі дерев сосни звичайної, що знаходяться в осередку впливу патогенного фактору, зокрема в осередку кореневої губки, є вищим, ніж на контролі. При цьому дерева, що залишились життєздатними, на тлі масового всихання характеризуються більшим вмістом цих сполук порівняно 3 індивідуумами, які мають зовнішні ознаки ураження.

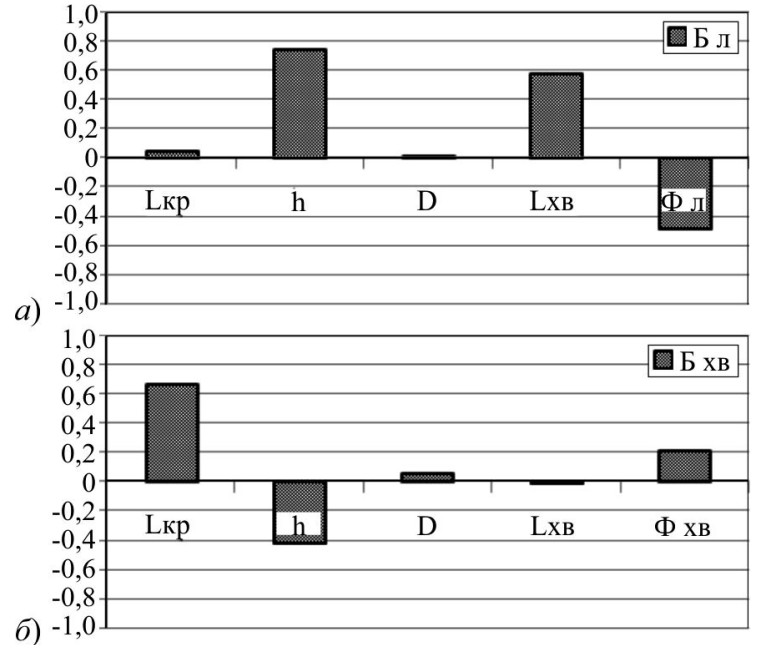

Рис. 3. Особливості кореляцій вмісту білків у лубі та хвої з таксаційними характеристиками дерев сосни звичайної, довжиною хвої та вмістом сполук фенольної природи: $a$ ) - вміст білків у лубі (Бл), мг/г; б) - вміст білків у хвої (Бхв), мг/г: $L_{\kappa p}-$ протяжність крони, м; $h$ - висота дерев, м; $D$ - діаметр дерев, мм; $L_{x 6}$ довжина хвої мм; $\Phi_{л}-$ сумарний вміст сполук фенольної природи у лубі; $\Phi_{x в}-$ сумарний вміст сполук фенольної природи у хвої

Між вмістом білків у лубі та довжиною хвої зв'язок середній і статично не підтверджений $(r=0,57)$. Між вмістом білків у лубі та діаметром, а також протяжністю крон зв'язок відсутній. Між вмістом білків і фенольних сполук у лубі простежується помірна негативна кореляція $(r=-0,49)$. Між вмістом білків у хвої (див. рис. 3, б) та протяжністю крон простежується сильна позитивна кореляція $(r=0,65)$. Напрямок зв'язку між вмістом білків у хвої та висотою дерев від'ємний, статистична достовірність такої кореляції не підтверджена $(r=-0,42)$. Зв'язок між вмістом білків і фенолів у хвої слабкий $(r=0,20)$.

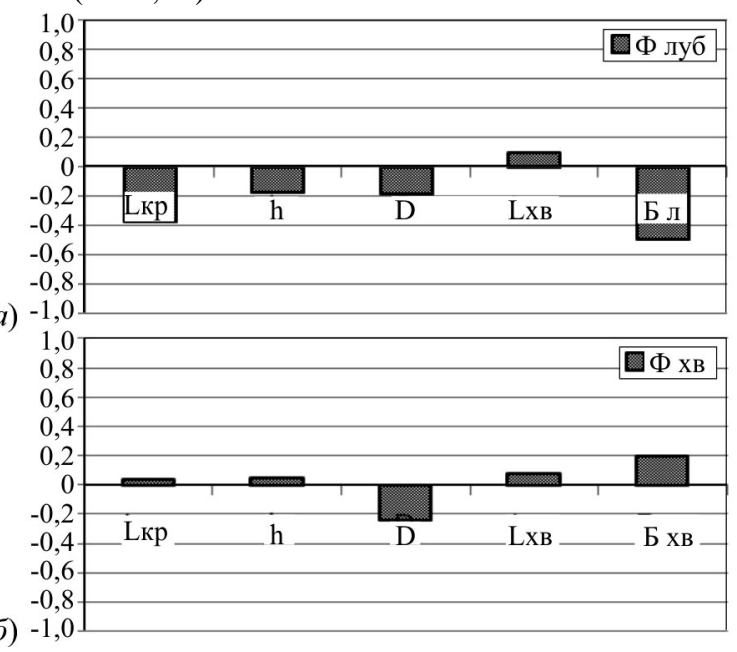

Рис. 4. Особливості кореляцій сумарного вмісту фенольних сполук у лубі та хвої з таксаційними характеристиками сосни звичайної, довжиною хвої та вмістом білків: $L_{\kappa p}-$ протяжність крони, м; $h$ - висота дерев, м; $D$ - діаметр дерев, мм; $L_{x 6}-$ довжина хвої мм; $5_{л}-$ вміст білків у лубі; $E_{x \varepsilon}-$ вміст білків у хвої

Тісних кореляцій між вмістом сполук фенольної природи у лубі та хвої і таксаційними показниками дерев (рис. 4) не виявлено (відповідно, $r=(-037--0,16) ; r$ $=(-0,24-0,05)$. Простежується тільки різний напрямок такого зв'язку. Детальний аналіз, проведений стосовно кожної сполуки окремо, виявив, що важливішу роль у взаємозв'язку з показниками продуктивності відіграють 
сполуки Ка у хвої. Між Ка і протяжністю крон та діаметрами дерев зафіксовано середній кореляційний зв'язок (відповідно, $\quad r=-0,60 ; \quad p_{0.01}>1,8 ; \quad r=-0,58$; $\left.p_{0.01}>1,7 ; p_{0.05}=2,3\right)$, статистичного підтвердження такого зв'язку не виявлено, проте від'ємний напрямок простежується в обох випадках.

Результати також свідчать про переважно від'ємну кореляцію між вмістом фенолів у лубі та хвої і таксаційними показниками дерев (від $r=0,08$ до $r=-0,37$ ). Протяжність крони істотно не впливала на довжину хвої $(r=0,35)$.

\section{Висновки}

Кращий санітарний стан відзначено у дерев сосни 3 довшою хвоєю. В осередку "короїдного" усихання сосни звичайної накопичення сполук фенольної природи у лубі та хвої сосни звичайної різниться. Вміст водорозчинних білків у хвої дерев є більшим, ніж у лубі, тоді як вміст проантоціанідинів i катехінів $€$ меншим. Функціональні залежності між вмістом біохімічних сполук та основними ростовими характеристиками i станом є дуже складними, оскільки результати біохімічних досліджень свідчать тільки про тенденції до причинно-наслідкового зв'язку між ними. Особливості вмісту фенольних сполук у лубі показали, що підвищений вміст проантоцианідінів та катехінів певною мірою протидіє проникненню та розповсюдженню стовбурових шкідників, що дає змогу таким деревам зберігати життєздатність на тлі масового всихання.

\section{References}

1. Beker, C., Turski, M., Kaźmierczak, K., Najgrakowski, T. (2020). Size and efficiency of Scots pine (Pinus sylvestris L.) assimilation $\begin{array}{lll}\text { apparatus. } & \text { Sylwan, } & \text { 164(1), }\end{array}$ https://doi.org/10.26202/sylwan.2019117

2. Belikov, V. V, Shrayber, M. S. (1972). Methods of analysis of flavonoid compounds. Farmatsiya, 1, 68-72. [In Russian].

3. Buzun, G. A., Dzhemukhadze, K. M., \& Mileshko, L. F. (1982). Determination of protein in plants using amido black. Fiziologiya rasteniy, 29(1), 198-204. [In Russian].
4. Costa, P., Bahrman, N., Frigerio, J., et al. (1998). Water-deficitresponsive proteins in maritime pine. Plant Mol Biol, 38, 587596. https://doi.org/10.1023/A:1006006132120

5. Dyshko, V. A. (2013). Features biodiversity and relationship of morphological and biochemical traits pine (Pinus sylvestris L.) in the enterprise "Chugueva-Babchanske LH". Vísnik KHNAU, 1, 203-208. [In Ukrainian].

6. Fedulov, Yu. P., Kotlyarov, V. V., \& Dotsenko, K. A. (2015). Resistance of plants to adverse environmental factors. Uch. pos. Krasnodar: KubGAU, 64 p. [In Russian].

7. Ivanova, Ye. V., Luksha, Ye. A., Kalinkina, G. I., \& Pogodin, I. S. (2016). Determination of catechins and leucoanthocyanins in the aerial and underground parts of Aconogonon divaricatum. Vestnik VolgGMU, 4(60), 118-120. [In Russian].

8. Julkunen-Tiitto, R. (1985). Phenolic constituents in leaves of northern willows: methods for the analysis of certain phenolics. Journal of Agricultural and Food Chemistry, 33(2), 213-217.

9. Kolupaev, Yu. Ye., \& Kosakivska, I. V. (2008). The role of signal systems and phytohormonesin the realization of plants stress respon. Ukr. Botan. Journ., 65(3), 418-430. [In Ukrainian].

10. Lapach, S. N, Chubenco, A. V., \& Babych, P. N., (2001). Statistical methods in biomedical research using Excel (2nd ed.). Kiev: Morion. [In Russian].

11. Mamaev, S. A. (1972). Forms of intraspecies variability of tree plants (the case of the Pinaceae family in the Urals). Moscow: Nauka, 283 p. [In Russian].

12. Meshkova, V. L., \& Borysenko, O. I., (2018). Prediction for bark beetles caused desiccation of pine stands. Lisivnytstvo i ahrolisomelioratsiya, 132, 155-161. [In Ukrainian].

13. Sanitarni pravila v lisakh Ukrainy. (1995). Redaktsii postanovi Kabinetu Ministriv Ukrainy vid 26 zhovtnya 2016 year, 756. Kyiv: Morion, 20 p. [In Ukrainian].

14. Sannikov, S. N., \& Petrova, I. V. (2003). Differentiation populations of Skots pine. Yekaterinburg: UrO RAN, 247 p. [In Russian].

15. Voytsekhivs'ka, O. V., Sytar, O. V., \& Taran, N. Yu. (2015). Phenolic compoundsi: research, biological activity, perspectives of stagnation. KHNAU, 1, 104-119. [In Russian].

16. Zhang, Yi., Ronald, R., \& Sederoff, Allona, I. (2000). Differential expression of genes encoding cell wall proteins in vascular tissues from vertical and bent loblolly pine trees. Tree Physiology, 20(7), 457-466. https://doi.org/10.1093/treephys/20.7.457

\section{N. Yu. Vysotska1, V. A. Dyshko1, A. N. Mykhaylichenko', A. I. Khromulyak', V. A. Klimko² \\ ${ }^{1}$ Ukrainian Research Institute of Forestry and Forest Melioration named after G. M. Vysotsky, Kharkiv, Ukraine ${ }^{2}$ State Enterprise "Kyiv Forest Research Station", Lyutizh, Ukraine}

\section{SOME FEATURES OF METABOLISM OF SCOTS PINE IN THE BARK BEETLE FOCUS IN KYIV POLISSYA}

In the context of global climate change, the relevance of research aimed at increasing the productivity and biological sustainability of forests is growing. The study of Scots pine (Pinus sylvestris L.), which occupies a wide area and is characterized by a complex intraspecific structure, attracts special attention. Outbreaks of mass breeding of bark beetle in Scots pine forests are one of the factors of abiotic stress. Plants that are periodically affected by stress are forced to adapt to it through physiological, biochemical, and anatomical and morphological rearrangements. Therefore, an important aspect of the formation of pine forest stands resistible to such stress factor as the attack of insects, is a biochemical indication of the state of the trees, which use the products of the main metabolism and secondary metabolites. In Kyiv Polissya, the morphological parameters of pine needles and the content of water-soluble proteins and low-molecular phenolic compounds (flavonols in pine needles; catechins, proanthocyanidins in pine needles and phloem) in Scots pine trees in the bark beetle focus were studied. The content of proteins and phenolic compounds was determined by a colorimetric method according to conventional methods. Some differences in the content of phenolic compounds in the phloem and needles of Scots pine have been established. The content of water-soluble proteins in the needles of Scots pine is found to be significantly higher than in phloem. The low-molecular phenolic compounds (proanthocyanidins, catechins) accumulate more intensively in the phloem. The variability of protein synthesis in both phloem and needles is low. Flavonol compounds are present only in pine needles. No significant relationships were found between the content of phenolic compounds and the taxonomic specifications of Scots pine trees. Against the background of mass death of Scots pine in Kyiv Polissya among weakened trees, more stable specimens are characterized by high protein activity, which indicates their significant positive effect on plant stability under stressors.

Keywords: Pinus sylvestris L.; stress; resistance; metabolites. 